\title{
A Cooperação na Deliberação Pública: Um Estudo de Caso sobre o Referendo da Proibição da Comercialização de Armas de Fogo no Brasil*
}

\author{
Ricardo Fabrino Mendonça \\ Com a colaboração de Débora Bráulio Santos
}

\section{INTRODUÇÃO}

$\mathrm{O}$ modelo de democracia deliberativa tem despertado um crescente interesse nas áreas de comunicação, filosofia e ciência política. Tal modelo põe a interação argumentativa no cerne da ação política, defendendo que, na contemporaneidade, leis, práticas sociais e instituições só podem ser legítimas se elaboradas e permanentemente escrutinadas por todas as pessoas que são por elas afetadas. Esse permanente processo de construção e de revisão deve ocorrer em processos públicos e abertos de troca de razões em diversas esferas discursivas, fazendo prevalecer a força do melhor argumento (Habermas, 1997; Hendriks, 2006; Cooke, 2000; Dryzek, 2000; Bohman, 1996). Como sintetiza Habermas, o paradigma deliberativo está alicerçado na ideia de um processo democrático que gera "legitimidade por meio de um procedimento de formação da opinião e da vontade que garante (a) publicidade e transparência para o processo deliberativo, (b) inclusão e igual

\footnotetext{
* O presente artigo foi apresentado no II Encontro da Associação Brasileira de Pesquisadores em Comunicação e Política (Compolítica), em 2007, beneficiando-se dos comentários de participantes do evento. Registram-se, aqui, agradecimentos a Daniela Paiva, por seu inestimável auxílio na coleta de dados, e aos integrantes do Grupo de Pesquisa em Mídia e Esfera Pública, da Universidade Federal de Minas Gerais (UFMG), e do Grupo de Pesquisa em Comunicação, Internet e Democracia, da Universidade Federal da Bahia (UFBA), sobretudo a Rousiley Maia e a Wilson Gomes. Agradecimentos também são devidos aos pareceristas anônimos de DADOS.
}

DADOS - Revista de Ciências Sociais, Rio de Janeiro, Vol. 52, n² 2, 2009, pp. 507 a 542. 
oportunidade de participação e (c) uma expectativa justificada de resultados razoáveis" (2006:413; tradução do autor).

Para Habermas, a "deliberação é uma forma exigente de comunicação, embora ela nasça das imperceptíveis rotinas ordinárias de demandar e fornecer razões" (ibidem). Com isso, o autor deixa claro que, apesar de cotidiana, a deliberação pública não é tão abrangente a ponto de encampar todas as interações comunicativas praticadas no seio da sociedade. A deliberação engloba os levantamentos recíprocos de pretensões de validade. Trata-se de uma prática argumentativa cooperativa restrita pela publicidade, a qual garante não apenas a acessibilidade das razões proferidas, mas governa o próprio teor dos argumentos defensáveis (Bohman, 1996).

Gutmann e Thompson (1996) também circunscrevem o escopo desse processo contínuo a partir de três princípios que devem regular as interlocuções deliberativas: reciprocidade, publicidade e accountability ${ }^{1}$. Querem dizer, em suma, que processos deliberativos são marcados por um vaivém argumentativo em que os participantes se respondem mutuamente, em arenas publicamente acessíveis, prestando contas sobre seus atos e proferimentos.

Esses atributos normativos que caracterizam a deliberação pública são vistos por muitos críticos como excessivamente exigentes para serem colocados em prática. É como se a democracia deliberativa fosse uma utopia irrealizável, que requeresse cidadãos benevolentes capazes de abrir mão de seus interesses em prol da coletividade. $\mathrm{O}$ fulcro dessa crítica está nas supramencionadas noções de cooperação e reciprocidade, que levam alguns a supor que a deliberação implica o apagamento dos conflitos e das competições, em uma espécie de discussão polida e sem emoções.

Neste artigo, defende-se, no entanto, que é a crítica que se mostra exigente demais, ao esperar que a agência recíproca e cooperativa seja destituída de interesses e emoções (Dahlberg, 2005). O modelo deliberacionista de democracia não depende de uma acepção tão restrita desses dois conceitos. Pensar a cooperação e a reciprocidade sob a ótica do co-operar, do agir em conjunto ou do referir-se mutuamente facilita a compreensão e a implementação da deliberação pública. É preciso ultrapassar a ideia de que a democracia deliberativa requereria uma república de anjos, como parecem supor certos críticos, e buscar entendê-la como uma prática que ocorre também em meio a disputas de poder e interesses. 
Como assinala Habermas, "a política dialógica e a instrumental [...] podem entrecruzar-se no medium das deliberações" (2002:285; ênfase no original). Brady (2004) é bastante convincente quando defende que os ideais habermasianos que estão na base da perspectiva deliberacionista não conduzem à supressão do agonismo. Ao contrário, eles evidenciam a possibilidade e a necessidade de diálogo entre diferentes posições, acabando por promovê-las. Nesse sentido, o cerne da noção de reciprocidade não precisa se conectar à ideia de altruísmo (ainda que não se oponha a ela). Tal cerne está na consideração do outro no momento em que se responde a esse outro.

É o delineamento dessas noções de cooperação e reciprocidade que se busca explorar ao longo deste artigo. Tais noções são tratadas de maneira sobreposta por se considerar que ambas refletem a mesma ideia no interior do modelo deliberacionista. A discussão tem início com uma breve apresentação das mencionadas noções, as quais ganham sentidos distintos em diferentes teorias. Aborda-se, aqui, a perspectiva considerada rica para se pensar a deliberação sem onerá-la a ponto de inviabilizá-la. Depois, é analisado, então, um exemplo empírico a fim de observar a existência de reciprocidade em casos em que os participantes não querem (nem podem) ceder ao objetivo final dos adversários, ainda que tenham de dialogar com os argumentos levantados por eles.

Explora-se, assim, o debate processado entre as duas frentes constituídas por ocasião do referendo a respeito da proibição da comercialização de armas de fogo realizado no Brasil em 2005. A análise dos programas televisivos veiculados pelas duas frentes revela uma intrincada trama de argumentos e de contra-argumentos, sendo inconcebível pensar que esses proferimentos são elaborados independentemente. Tais discursos são produzidos na operação em conjunto que estrutura o processo deliberativo. Desde o início das campanhas, cada frente configura sua fala tendo em vista os argumentos defendidos por adversários e procura dar respostas a eles. É o que se verá na última seção, com a análise de debates processados em torno de um dos eixos argumentativos: a questão dos direitos.

\section{RECIPROCIDADE E COOPERAÇÃO COMO PRINCÍPIOS QUE INDEPENDEM DO ALTRUÍSMO}

A filosofia moral e a ciência política demonstram grande interesse pela noção de reciprocidade e pela questão da cooperação social. Basta lembrar os diversos estudos sobre a racionalidade da cooperação (patentes 
em enfrentamentos do dilema do prisioneiro e da questão do free rider $)^{2}$ ou a perspectiva da cultura cívica, inaugurada nos anos 1960 pelo clássico estudo de Almond e Verba ${ }^{3}$. Também no campo da sociologia e da antropologia, a reciprocidade e a cooperação são aspecto central para a compreensão dos processos de interação e troca social, sendo recorrentes as menções ao trabalho de Parsons e ao clássico ensaio de Mauss (1974) sobre as trocas em sociedades tradicionais.

Grande parte desses enfoques permanece, todavia, muito atada à ideia de uma dicotomia entre o altruísmo e o autointeresse (Adloff e Mau, 2006). A cooperação e a reciprocidade são vistas como envolvendo colaboração e auxílio mútuo. Trata-se de uma espécie de favor ou cortesia que os sujeitos deveriam (embora frequentemente não o façam) conceder, benevolentemente, uns aos outros, seja no intuito de obter mais benefícios para si próprios, seja porque aspiram a realizar uma sociedade mais fraterna e, por isso, melhor. A cooperação se torna uma espécie de combinação paradoxalmente sintética entre altruísmo e egoísmo: auxiliar o próximo é o melhor que se pode fazer para si mesmo ${ }^{4}$.

As ideias de reciprocidade e cooperação em que se ancora o modelo deliberacionista de democracia não necessariamente dependem dessa interpretação colaboracionista, que opera em termos de auxílio e concessão ao outro. Ainda que essas ideias de auxílio e concessão pareçam emergir de certas interpretações de defensores e críticos da deliberação, é mais frutífero trabalhar com um viés que concebe essas duas noções em termos de co-operação e responsividade. A democracia deliberativa não exige que cada participante aceite a perspectiva dos outros, nem que adote uma espécie de altruísmo ingênuo, abrindo mão de suas próprias preferências. Mesmo porque se aposta que tais preferências não preexistem à interlocução. Esse modelo discursivo de democracia não é um clube exclusivo para cavalheiros, conforme adverte Dryzek (2000:169). Tudo o que é necessário é que os atores participantes se reconheçam reciprocamente como interlocutores, encampando as posições defendidas pelo outro no próprio discurso.

Isso pode se dar tanto pela contestação de fragmentos quanto pelo questionamento da totalidade do discurso do outro. A ideia aqui defendida é que a produção de argumentos genéricos e publicamente defensáveis não necessariamente significa uma convergência das opiniões dos participantes. É o que evidenciam Gutmann e Thompson (1996), por exemplo, ao explorar casos como o debate sobre o aborto, a 
A Cooperação na Deliberação Pública: Um Estudo de Caso sobre o Referendo...

partir da ideia de economia do desacordo moral. A deliberação requer que os participantes formulem respostas mútuas, englobando as perspectivas e os contra-argumentos propagados por adversários. Demanda, em síntese, que os atores não se ignorem, mas operem em conjunto, em um jogo argumentativo de trocas de razões.

Como destacam Gutmann e Thompson, a reciprocidade é uma forma de mutualidade que implica o reconhecimento intersubjetivo: "Cidadãos que usam a razão reciprocamente podem reconhecer uma posição como moralmente respeitável mesmo se a veem como incorreta" (ibidem:2-3; tradução do autor). Eles precisam buscar modos mutuamente aceitáveis de solucionar desacordos morais, o que demanda esse reconhecimento das visões do outro, mas não sua aceitação. Embora partindo de premissas distintas, Dryzek e Niemeyer (2006) sustentam posição semelhante quando desenvolvem o conceito de metaconsenso. De acordo com eles, a deliberação não depende de um consenso substantivo em termos de valores, crenças e preferências, visando a acordos que atribuam legitimidade às posições de outros interlocutores. Chambers e Kopstein (2001:839) também defendem perspectiva semelhante quando alegam que a "reciprocidade envolve o reconhecimento de outros cidadãos como agentes morais merecedores de civilidade, incluindo-se aqueles com quem temos profundos desacordos". O que é preciso é que haja responsividade, sendo que esta "tem o efeito de equalizar falante e ouvinte de modo que possa haver discurso" (Warren, 2006:169; tradução do autor).

Nesse jogo contestatório, a reciprocidade se faz evidente não apenas na consideração dos outros, mas também no apelo a razões que possam vir a ser aceitas por eles, o que requer que não sejam ignorados. Como expõe Macedo, ao analisar a já mencionada obra de Gutmann e Thompson, a reciprocidade deliberativa significa que os "cidadãos devem apelar para o próprio entendimento sobre princípios morais mutuamente reconhecidos" (1999:7; tradução do autor). Isso quer dizer que precisam formular seus argumentos com base em quadros interpretativos partilháveis pelos concidadãos: "A partir de uma perspectiva deliberativa, um cidadão deve oferecer razões que possam ser aceitas por outros que estejam similarmente motivados a encontrar razões passíveis de aceitação pelos outros" (Gutmann e Thompson, 1996:53).

Como se nota, a reciprocidade prevista na proposta de Gutmann e Thompson está embasada na construção de justificativas mutuamente 
aceitáveis e busca manter a cooperação social entre os cidadãos. Ela se distingue da prudência e da imparcialidade, porque é movida pelo desejo de justificar-se, e não pelo autointeresse, como na primeira, ou pelo altruísmo, como na segunda. Enquanto a prudência aposta na barganha como modo de garantir vantagens mútuas, e a imparcialidade apela para a demonstração universal, a reciprocidade vê na deliberação, na troca de razões, o alicerce dos vínculos morais de uma comunidade política (ibidem).

\begin{tabular}{|l|l|l|l|l|}
\hline Princípio & Justificação & Motivo & Processo & Objetivo \\
\hline Prudência & $\begin{array}{l}\text { Mutuamente } \\
\text { vantajoso }\end{array}$ & Autointeresse & Barganha & Modus vivendi \\
\hline Reciprocidade & $\begin{array}{l}\text { Mutuamente } \\
\text { aceitável }\end{array}$ & $\begin{array}{l}\text { Desejo de se } \\
\text { justificar para } \\
\text { os outros }\end{array}$ & Deliberação & $\begin{array}{l}\text { Deliberação } \\
\text { Acordo/desa- } \\
\text { cordo }\end{array}$ \\
\hline Imparcialidade & $\begin{array}{l}\text { Universalmen- } \\
\text { te justificável }\end{array}$ & Altruísmo & Demonstração & $\begin{array}{l}\text { Visão compre- } \\
\text { ensiva }\end{array}$ \\
\hline
\end{tabular}

Fonte: Gutmann e Thompson (1996:53).

A perspectiva de Gutmann e Thompson ainda pode ser encarada, todavia, como demasiadamente exigente, visto demandar que cada interlocutor construa suas perspectivas de modo que possam ser aceitas pelos outros interlocutores. Tal demanda, se estabelecida aprioristicamente, pode eliminar importantes contribuições a certos processos deliberativos, já que nem todos os atores têm habilidade ou vontade de se colocar por meio de razões públicas. Um viés mais frutífero parece depositar essa construção de perspectivas mutuamente aceitáveis não nas escolhas de atores em si, mas no próprio processo deliberativo (Dryzek, 2000; Bohman, 1996).

A concepção bohmaniana de cooperação parece bastante interessante por depositar suas esperanças na prática dialógica. Também nessa perspectiva, a deliberação não depende de um suposto apagamento imparcial das próprias opiniões diante do interlocutor: "Minhas necessidades permanecem como minhas mesmo se publicamente compreensíveis" (Bohman, 1996:45; tradução do autor). Essa visão não altruísta de cooperação deliberativa é explicitada em diversas passagens do livro de Bohman, a começar por sua ligação entre a noção e a ideia de um processo continuado de accountability em situações problemáticas. Fica patente que a cooperação que ele tem em mente não é uma concessão de auxílios e favores, nem algo que pode ser localizado no 
interior dos indivíduos sob a forma de virtudes. Trata-se de um processo crítico, de prestação de contas e de troca de razões. Tanto que ele defende que a deliberação é necessária em casos de ruptura da coordenação social (ou seja, em situações em que os atores não teriam bons motivos para agir em benefício dos outros) exatamente para que se restabeleça o processo mais amplo de cooperação social (ibidem:33). O objetivo não é que os atores abram mão de seus interesses, mas que consigam operar em conjunto com outros, respeitando-os, na medida em que os consideram interlocutores válidos e respondem a eles.

Essa questão também é ressaltada por Bennett et alii (2004) em pesquisa sobre a possibilidade de um debate global por meio de cena jornalística. Entre os operadores analíticos empregados pelos autores está a responsividade, que eles caracterizam como o ato de fornecer respostas e contra-argumentos aos proferimentos de outros atores. $\mathrm{Na}$ trilha de Bennett et alii, Maia (2008) destaca essa mesma questão ao propor alguns operadores analíticos voltados para a análise de processos deliberativos nos media. A pesquisadora reúne os termos responsividade e reciprocidade em um mesmo indicador, explicando que, com isso, busca averiguar a "interação discursiva entre os atores e seus discursos", atentando para a possibilidade de respostas mútuas, para o caráter das justificações produzidas e para os modos de endereçamento recíproco (ibidem:105). Em análise dos debates sobre o referendo do desarmamento travados em veículos da grande imprensa, Maia, Buarque e Brischiliari (2006) afirmam que a reciprocidade é construída no movimento do debate.

A ideia-chave presente nesses estudos é a de um processo argumentativo em que atores se dirigem respostas recíprocas e, ao fazê-lo, consideram a existência do outro e de seus proferimentos. A cooperação deliberativa está ancorada, assim, no princípio normativo do ideal-role-taking, que Habermas discute em sua teoria da ação comunicativa a partir das proposições de Mead. O pragmatista da Escola de Chicago analisa o ato social não como fruto de indivíduos monádicos, mas como o resultado de uma situação interacional em que a própria relação precede e configura o ato. Para Mead (1993), os sujeitos não são selves autônomos e independentes que planejam seus atos individualmente; eles organizam suas condutas com base na presença do outro, visto que as expectativas sobre as possíveis reações dos atores a quem se dirige determinada ação atravessam e afetam esses mesmos atos. Segundo ele, "estamos constantemente provocando em nós mesmos as reações que des- 
pertamos em outras pessoas, de tal modo que incorporamos em nossa conduta as atitudes e gestos delas" (ibidem:108; tradução do autor).

Esse atravessamento se dá por meio de uma intersubjetividade partilhada (o "outro generalizado", nos termos de Mead), que permite ao indivíduo colocar-se no lugar do outro. Ao assumir o papel do outro (role-taking), é possível vislumbrar suas posições, possíveis reações e incorporá-las no próprio ato: "Essa adoção do papel do outro [...] tem importância para o desenvolvimento da atividade cooperativa. O efeito imediato de tal adoção de papel reside no controle que o indivíduo logra exercer sobre sua própria reação" (ibidem:272). Mead percebe que os processos comunicativos são a base da cooperação e não restringe o significado desta à ideia de altruísmo. A cooperação social, como já dito, surge quando membros de uma comunidade de linguagem assumem as atitudes sociais uns dos outros reciprocamente (ibidem:313).

Essa ideia revela o cerne da reciprocidade deliberativa discutida neste artigo. Ela se configura no reconhecimento da existência do outro e na percepção de que se age diante dele, o que afeta o próprio agir. Não se trata de uma reciprocidade benevolente típica da república dos anjos. Até mesmo práticas estratégicas dependem dessa prática de assumir a atitude do outro. Habermas (1983:100) também adota essa perspectiva, compreendendo que a cooperação está alicerçada na incorporação da interpretação do outro na própria interpretação.

O co-operar deliberativo requer apenas, portanto, que interlocutores se reconheçam como tais e produzam seus argumentos considerando a existência dos outros ${ }^{5}$. Tal consideração depende, em suma, de três dimensões: 1) ouvir o outro; 2) responder a ele;3) levar em conta seus argumentos e perspectivas quando da elaboração de contra-argumentos. Essa concepção tem a vantagem de libertar a deliberação das pesadas exigências de uma reciprocidade altruísta, permitindo vislumbrar o exercício da deliberação mesmo em casos em que os deliberantes não desejam deixar-se convencer mutuamente.

\section{REFERENDO DO DESARMAMENTO: UM ESTUDO DE CASO}

Buscando observar uma dessas situações em que cada debatedor não poderia, em nenhuma hipótese, ceder à posição dos outros, serão analisadas, agora, trocas argumentativas travadas por ocasião do referendo sobre a comercialização de armas de fogo no Brasil. A análise desenvolvida aqui volta seu foco especificamente para as campanhas te- 
levisivas veiculadas no Horário Gratuito de Propaganda Eleitoral (HGPE). Seguindo James (2004), percebe-se que as campanhas eleitorais podem ser entendidas como processos deliberativos.

Claro está que os discursos analisados são de atores diretamente interessados no resultado da votação; atores que se declaravam abertamente defensores de uma determinada posição, o que traz implicações para as próprias características do debate. Por um lado, os interlocutores não desejam deixar-se convencer mutuamente. Uma frente não poderia mudar totalmente seu posicionamento. Por outro lado, verifica-se o esforço por constituir argumentos potencialmente aceitáveis pelo adversário, a fim de convencer o público em geral. Embora a possibilidade de mudança de posição por parte das frentes fosse nula, o mesmo não acontecia em relação aos eleitores, que poderiam modificar seu voto diante do discurso adversário. Cada frente se esforçou para construir argumentos que pudessem ser potencialmente aceitos por um cidadão motivado a votar no lado adversário, tendo em vista convencê-lo a mudar de posição.

Além disso, as frentes exibiam suas campanhas com uma frequência diária, em uma dinâmica na qual à exibição de uma campanha se seguia imediatamente a exibição de outra. Tal dinâmica criava um contexto propício a um toma-lá-dá-cá argumentativo, em que a agilidade em dar respostas era fundamental. Sendo assim, a atitude de responder não se apresenta como uma escolha altruísta ou uma virtude deliberativa dos agentes, mas quase como uma exigência da dinâmica de exibição das campanhas. Essa mesma dinâmica age no sentido de estabelecer um debate governado pela força do melhor argumento, o que é comprovado pela análise das trocas argumentativas. O esforço feito era sempre o de construir argumentos bem fundamentados e responder aos argumentos adversários, sendo possível vislumbrar aí uma operação em conjunto (co-operação). Para que um debate seja minimamente deliberativo, a disputa não precisa ser eliminada, desde que seja uma disputa argumentativa, na qual fatores extradiscursivos não estejam atuando de forma antidemocrática.

\section{O Referendo}

Realizada no dia 23 de outubro de 2005, a consulta popular levou 95.375.824 cidadãos brasileiros às urnas para responder à pergunta: “O comércio de armas de fogo e munição deve ser proibido no Brasil?". O referendo estava previsto no art. 35 do Estatuto do Desarmamento (Lei 
no 10.826 ), que entrou em vigência em dezembro de 2003, após um longo processo político promovido por organizações não governamentais (ONGs), movimentos sociais e parlamentares envolvidos com a questão da violência urbana e da segurança pública ${ }^{6}$. O resultado da consulta foi a vitória do "não", com 63,94\% dos votos, e a derrota do "sim", com $36,06 \%$.

O processo do referendo não se restringiu, contudo, ao voto dos eleitores. Desde o Decreto Legislativo no 780, de 6 de junho de 2005, que autorizou a realização da consulta popular, intensificaram-se movimentações e debates acerca da proibição da venda de armas de fogo. No Congresso, as posições favoráveis e contrárias à proibição ganharam representantes oficiais: a Frente Parlamentar por um Brasil sem Armas, presidida pelo senador Renan Calheiros (Partido do Movimento Democrático Brasileiro - PMDB-AL), e a Frente Parlamentar pelo Direito da Legítima Defesa, presidida pelo deputado Alberto Fraga (Partido da Frente Liberal - PFL-DF). Elas ficaram responsáveis por promover o debate na sociedade, obtendo grande visibilidade nos meios de comunicação ${ }^{7}$, incluindo o direito ao HGPE no rádio e na TV (nove minutos diários para cada frente, além de vinte inserções de trinta segundos ao longo da programação, em um período de vinte dias).

O debate travado entre as duas frentes se inseriu em um processo discursivo e social bastante amplo, envolvendo os media ${ }^{8}$, diversas entidades da sociedade civil, conversações corriqueiras entre cidadãos em suas vidas ordinárias, e-mails de todos os teores ${ }^{9}$, pregações em igrejas, discursos de parlamentares e manifestações de $\operatorname{artistas}{ }^{10}$. Nessa trama de interlocuções atualizada em diversas esferas, discursos dos mais diferentes matizes se fizeram disponíveis. Estes foram, sem dúvida, importantes para a expressiva vitória do "não", que, em uma virada incrível ${ }^{11}$, conseguiu dissociar o referendo da ideia de desarmamento (apoiada por $80 \%$ da população) e ligou a manutenção da venda de armas às lutas por direitos.

Algumas justificativas são apresentadas por diferentes autores para essa virada do "não", sendo interessante mencionar sete delas:

1) A ineficiência da propaganda eleitoral do "sim", que pecou pela falta de planejamento estratégico e pela aposta na fala descontextualizada de artistas (Mota, 2006; Lissovsky, 2006).

2) A conjuntura política, marcada por denúncias de corrupção e pelo sentimento de que o governo é omisso em relação à segurança pú- 
A Cooperação na Deliberação Pública: Um Estudo de Caso sobre o Referendo...

blica, o que transformou o voto em instrumento de protesto (Sorj, 2006; Cunha, 2006; Mota, 2006).

3) A desmobilização do "sim" em virtude da crença na vitória fácil (Lissovsky, 2006; Mota, 2006; Sorj, 2006).

4) A formulação da pergunta do referendo (Correa e Nunes, 2006; Mota, 2006).

5) A adoção das normas de uma eleição convencional, o que impediu a participação de associações que recebessem recursos do exterior (Sorj, 2006; Mota, 2006).

6) A complexidade da temática em questão, o que gerava medo da mudança (Mota, 2006; Araújo e Santana, 2006).

7) $\mathrm{O}$ fato de a maioria dos parlamentares não ter se posicionado em relação ao referendo: dos 513 deputados federais, por exemplo, 312 $(60,8 \%)$ não se filiaram a nenhuma frente (Araújo e Santana, 2006).

Neste artigo, porém, o intuito não é discutir as causas da vitória do "não". A análise se volta para as trocas de argumentos entre as duas frentes na propaganda televisiva. Trocas que foram estrategicamente coordenadas por marqueteiros: Chico Santa Rita, pelo lado do "não", e, pelo lado do "sim", inicialmente Paulo Alves, substituído em meados da campanha por Luiz Gonzáles. Como lembra Christina da Cunha, "neste referendo a propaganda gratuita na televisão assumiu uma importância ímpar, pois não se tratava de uma eleição ordinária, de uma disputa entre candidatos e partidos, mas de uma idéia a respeito de um tema que a população brasileira não se debruçou antes para pensar" $(2006: 58)^{12}$.

Percebe-se, portanto, que as campanhas se configuraram como um espaço privilegiado de debate, tanto porque forneceram insumo para discussões em diversos espaços da sociedade quanto porque foram, elas mesmas, momento de intercâmbio de razões. O caráter dialógico das campanhas do referendo das armas também foi apontado por Fuks e Paiva (2006), embora a análise deles se volte mais para as especificidades dessa campanha em comparação com aquelas de uma eleição convencional. Para os autores, "os argumentos que surgem no contexto de cada campanha só são plenamente inteligíveis quando se reconhece o 'diálogo' que ele estabelece com a campanha adversária" (ibidem:229). A permanente necessidade de dar respostas ao adversário e o fato de tais respostas deverem encampar as posições desse oponente 
permitem observar a existência de reciprocidade e de cooperação nesses embates, características importantes de processos deliberativos.

\section{Apontamentos Metodológicos}

Como já mencionado, para proceder a este estudo, foram analisadas as campanhas televisivas veiculadas no HGPE. Assistiu-se aos quarenta programas veiculados por cada frente entre os dias 1o e 20 de outubro de 2005, sendo que esse primeiro contato com o material serviu para a elaboração de um esquema geral sobre os eixos argumentativos em torno dos quais se travaram debates.

A ideia de eixos argumentativos está fortemente ligada à noção de enquadramento (frame), que tem grande (e diversificada) aplicação no campo das ciências sociais ${ }^{13}$. As raízes dessa noção se encontram na apropriação que Goffman (1986) faz da obra de Gregory Bateson. Goffman usa essa noção para abordar as estruturas interpretativas que organizam o modo como os sujeitos interpretam o mundo e agem sobre ele. Trata-se de princípios estruturadores (ready-made interpretativos) que atuam como esquemas intersubjetivos que guiam os sujeitos (ibidem:345). Quadros operam por meio de saliência e de seleção, recortando a realidade e permitindo que ela seja enfocada e transformada em discurso (Entman, 1993; Mouillaud, 2002). Enquadrar é, de acordo com Goffman (1986), algo inerente à própria comunicação e à ação social de modo mais amplo.

A questão é que o conceito de enquadramento deu origem a estudos de naturezas muito diferentes (Porto, 2004). Na área de comunicação e política, nota-se, por exemplo, copiosa produção sobre framing effects, em estudos preocupados com questões de agenda setting e priming (Chong e Druckman, 2007a; 2007b; Druckman e Nelson, 2003; Weaver, 2007; Reese, 2007; Druckman, 2004; Levin, 2005; Callagham e Schnell, 2001). Nessas investigações, frames são tomados como instrumentos escolhidos estratégica e individualmente para influenciar a opinião pública. Outras investigações, entretanto, chamam a atenção para as raízes culturais e internacionais da proposta goffmaniana, afirmando que frames não são simplesmente criados e mobilizados estrategicamente por indivíduos, mas apropriados por eles a partir de redes sociais e intersubjetivas de sentido (Steinberg, 1998; Van Gorp, 2007). Neste artigo, a interpretação da noção de frames parte da premissa de que eles são enrai- 
A Cooperação na Deliberação Pública: Um Estudo de Caso sobre o Referendo...

zados sócio-histórica e culturalmente, mas também percebe a dimensão estratégica da mobilização desses quadros nos discursos políticos.

Os passos desta análise se ligam à tradição dos estudos de enquadramento de dois modos. O levantamento inicial dos eixos argumentativos se conecta à apropriação de Gamson e Modigliani (1989) da noção, quando propõem o conceito de pacotes interpretativos. Para os autores, pacotes interpretativos são ideias organizadoras que sugerem "o que está em questão" e estruturam uma discussão pública (ibidem:3). Pacotes orientam a produção de proferimentos, comportando um grande número de argumentos, posições e discursos. Nota-se, assim, que a noção funciona como um conceito amplo. Um pacote aglomera muitos possíveis enquadramentos. Trata-se de um macroenquadramento a partir do qual se derivam subenquadramentos. Pacotes falam de um campo de sentido que abre campos de possibilidades para a construção de argumentos e posições, muitas vezes, divergentes.

A ideia de eixos argumentativos é exatamente essa. Buscou-se observar os eixos em torno dos quais o debate do referendo se construiu; os campos de sentido nos quais foi travado. A análise dos programas da campanha do referendo revelou a forte presença de cinco eixos (ou pacotes) principais: segurança pública, economia, direitos, problematização do referendo e qualidade de vida ${ }^{14}$. Ainda que alguns desses eixos se cruzem e haja pontos de sobreposição entre eles, cada um estrutura um debate autônomo no interior da discussão mais geral do referendo. No interior do eixo da segurança pública, a troca de argumentos entre as duas frentes gira em torno da indagação sobre o efeito da proibição da comercialização das armas na segurança pública. No eixo da economia, o debate diz respeito, basicamente, à questão de qual classe social seria favorecida pela proibição: os ricos ou os pobres. No eixo dos direitos, a discussão busca refletir se tal proibição representaria a proteção ou o cerceamento de direitos e liberdades dos cidadãos. A problematização do referendo engloba as críticas e os elogios ao processo de elaboração do Estatuto do Desarmamento e ao próprio processo de consulta popular por meio do referendo. Por fim, no eixo da qualidade de vida, discutiu-se o resultado de sua utilização sobre a qualidade de vida da população e sobre o caráter das pessoas que defendem ou não a proibição.

Constatados os eixos, iniciou-se um processo de levantamento dos principais argumentos apresentados pelas frentes. Em uma varredura pelo recorte empírico, foram listados todos os argumentos mobiliza- 
dos ao redor de cada eixo a fim de captar os principais enquadramentos mobilizados e as ideias derivadas deles. Nesse ponto, o uso da noção de enquadramento é mais específico do que na análise inicial de identificação dos eixos argumentativos. Buscou-se perceber como os discursos enquadram a realidade de maneiras diferentes no interior de um determinado eixo (pacote interpretativo). Visto que o eixo é o macroenquadramento, que funciona como um campo de sentido abrigando vários possíveis enquadramentos, procurou-se mapear esses enquadramentos que compõem o eixo.

Essa análise mais fina está alicerçada na proposta de Breton (2003) de pensar a dinâmica do argumentar por meio de dois momentos-chave que configuram o duplo gatilho argumentativo: o enquadramento e o vínculo. De acordo com Breton, a lógica da construção argumentativa requer esses dois momentos: "A primeira etapa visa construir um real comum ao orador e ao auditório. Nesta comunhão o segundo tempo da argumentação se apoiará para construir um vínculo entre este acordo e a opinião proposta" (ibidem:67). Os argumentos de enquadramento dão o passo inicial ao produzir um contexto partilhado, enquanto os de vínculo ou ligação exprimem uma opinião que faz sentido dentro daquele molde previamente estabelecido. Essa ligação pode se dar por dedução ou por analogia ${ }^{15}$.

Executada a empreitada de identificar os enquadramentos mobilizados no interior dos eixos argumentativos e os vínculos construídos a partir deles, buscou-se observar a forma como os argumentos se interpelavam. O objetivo era atentar para o modo como os discursos compõem uma complexa rede simbólica. Nessa rede, eles se chocam, respondem-se, convocam-se. Pensar a cooperação deliberativa é atentar para esses cruzamentos, evidenciando que os atores sociais não simplesmente apresentam suas posições, mas as elaboram em um palco interacional que pressupõe a existência de outros interlocutores, pelos quais são atravessados.

Dada a dimensão do material empírico, optou-se por focar um dos eixos do debate: a questão dos direitos. Embora os outros eixos tenham se mostrado bastante ricos, o tamanho e o escopo do artigo não viabilizam a análise de todos eles. Vale observar ainda que, embora a cronologia do desenvolvimento do debate seja fundamental, nem sempre ela é o principal indicador da existência ou não de reciprocidade. Isso porque as campanhas midiáticas não são as únicas instâncias discursivas 
envolvidas na discussão; muitos dos argumentos apresentados pelas frentes na TV estão em franco diálogo com discursos em circulação em outras instâncias (midiáticas e não midiáticas), incluindo-se aí as pesquisas de intenção de votos (Fuks e Paiva, 2006:229). As próprias formulações iniciais das frentes já se colocam como respostas a dúvidas ou como discursos contrários, em um debate temporalmente distendido que começa bem antes do início da veiculação do HGPE e se estende ao longo dos vinte dias de campanha. É preciso entender os processos deliberativos não de um modo simplista, que os reduziria ao debate entre as duas frentes, mas como um grande jogo dialógico, atravessado por diversos autores. Nesse jogo, as campanhas se apresentam como lances discursivos importantes e muito visíveis, e não como lances independentes do quadro geral que configura a partida.

\section{UM EMBATE PELA DEFINIÇÃO DOS DIREITOS}

A troca de argumentos entre as duas frentes processada no interior desse eixo gira em torno de uma pergunta central: afinal, a proibição da comercialização das armas de fogo representa a proteção de um direito dos cidadãos ou o cerceamento de uma de suas liberdades? Cada lado se propõe defensor de um direito básico. A frente do "não" apela para o valor da liberdade individual e se apresenta como advogada do direito de legítima defesa e de escolha (escolher possuir uma arma ou não). Já a frente do "sim" afirma defender o direito à vida e associa sua campanha à luta pela paz. Nota-se que os debates acabam se voltando para a própria definição da noção de direitos, fazendo-se recorrente um movimento pendular entre concepções individuais e coletivas. O bem-estar de indivíduos e o bem comum se apresentam frequentemente como polos de uma dicotomia que definiria a ideia de cidadania.

A análise desse eixo é extremamente rica porque traz exemplos em que se verifica não apenas uma incorporação do argumento alheio com o objetivo de contestá-lo, mas o reconhecimento da legitimidade e da eficácia do discurso oponente, com o objetivo de se apropriar dele. Em diversos momentos, uma frente parece reconhecer a eficácia do enquadramento criado pela outra e acaba por adotá-lo, visando, porém, a estabelecer um vínculo argumentativo diferente. Embora essa apropriação tenha fins estratégicos e possa ser pensada como uma utilização dos argumentos do adversário, ela obriga deslocamentos nas próprias perspectivas e levanta um terreno partilhado, no qual cada frente busca dar 
sua própria interpretação: afinal, a que direitos os cidadãos têm direito? Além disso, qual é a melhor forma de estabelecê-los?

\section{Entre o Medo da Perda da Liberdade e a Conquista do Direito à Vida}

A discussão que abre o debate do referendo, no que concerne à questão dos direitos, diz respeito à possibilidade de perda ou ganho de um direito. O enquadramento mais amplo mobilizado pela frente do "não" vincula a proibição à perda de um direito e ao cerceamento da liberdade: "Mais do que uma simples proibição, o que está em jogo é a perda de um direito seu, é não abrir mão de sua liberdade" (PN, FN, $10 / 10)^{16}$. Já no primeiro programa, $\mathrm{o}$ "não" recorre à fala autorizada de professores universitários para reforçar esse enquadramento. Um professor da Pontifícia Universidade Católica de São Paulo (PUC-SP) diz que "a lei não pode tirar um direito que a Constituição outorga".

Um dos vínculos criados dentro desse enquadramento insiste na ameaça que o poder do Estado representa para a sociedade civil em relação ao cerceamento da liberdade e à vulnerabilidade da democracia, especialmente em um país como o Brasil, onde muitos direitos do cidadão já são desrespeitados. De caráter analógico, o vínculo busca relacionar a sistemática denegação de direitos que marca o status social de uma ampla parcela da sociedade brasileira ao referendo. Afirma-se que a retirada de um direito - no caso, o direito de ter uma arma - pode levar à perda de diversos outros direitos. Ao longo de toda a campanha, esse enquadramento (proibição = perda de direito) é incessantemente mobilizado para afirmar que o voto no "sim" representa uma grande ameaça à democracia ${ }^{17}$ :

(Locutor) O ser humano nasceu para ser livre. Há poucos anos, vimos Nelson Mandela sair da prisão para acabar com o apartheid e libertar os negros na África do Sul. Na China, um homem sozinho enfrentou uma coluna de tanques, defendendo a liberdade. Na Alemanha, o povo derrubou o Muro de Berlim e abriu as fronteiras para a liberdade. (Carmen Cestari) No Brasil, também foi preciso lutar para impedir que nos tirassem a liberdade. (Locutor) Havia uma ditadura. Muitos direitos do cidadão foram suprimidos. O povo foi proibido até de votar. E quem discordava podia ser preso e torturado. Mas a vontade popular foi mais forte. O povo tomou as ruas. O movimento das Diretas Já traduziu um desejo que não podia mais ser contido: o resgate dos direitos civis. A reconquista da liberdade foi a resposta do povo aos anos de proibição. 
(Carmen Cestari) Agora, vai ser preciso lutar de novo pra defender os nossos direitos. Eu mesma, assim como muitos de vocês, nunca pensei em ter uma arma. Mas também não quero perder o direito de ter, nem quero tirar esse direito de muitas pessoas que precisam ter (PN, FN, 1 o $/ 10)$.

Essa fala evidencia um dos vínculos argumentativos estabelecidos dentro do enquadramento mais amplo (proibição = perda de direito): um cidadão que não quer ter uma arma hoje pode querer amanhã e, ainda, não deve tirar o direito do outro de possuí-la. "Se votar 'sim', você nunca mais poderá ter arma. Se votar 'não', você poderá ter arma, mas não precisa ter" (PV, FN, 16/10). Dedutivo, o vínculo infere consequências do enquadramento para apontar uma situação futura que pode contradizer os interesses de alguns cidadãos.

Tal argumento é repetido enfaticamente ao longo da campanha do "não", por meio das falas do locutor, da apresentadora Carmen Cestari, de depoimentos de especialistas e de pessoas comuns. No programa noturno do dia 6/10, por exemplo, Carmen Cestari diz que "está escrito no art. 3ํ da Declaração Universal dos Direitos Humanos: 'Toda pessoa tem direito à vida, à liberdade e à segurança pessoal'. É partindo desse princípio que vamos conhecer histórias de pessoas que já lutaram muito e não podem perder os direitos conquistados, como dona Jane". A empresária, caracterizada como uma mulher lutadora, que venceu na vida, diz que nunca abriu mão de seus direitos e não vai abrir agora. Afinal, se hoje ela não quer uma arma, amanhã pode querer.

Fica claro que, nesse momento, os argumentos da frente do "não" se concentram em torno da defesa de direitos individuais clássicos: a liberdade e o direito de escolha. Além disso, parte-se de uma concepção de segurança centrada no indivíduo e exercida por ele: é preciso que eu tenha armas para defender minha vida, minha casa, minha família.

A esses argumentos a frente do "sim" responde com duas estratégias: a) a defesa do direito à vida ("Arma é morte. 'Sim' é vida." - PN, FS, $7 / 10)$; b) a defesa de que segurança não é algo a ser resolvido individualmente, tratando-se de um problema coletivo ${ }^{18}$. Uma fala recorrente no discurso do "sim" exemplifica o apelo a uma concepção coletiva de segurança: "Se uma vida for salva, a proibição já terá valido a pena". Evidencia-se uma posição ética diante da vida humana, sugerindo que 
os adeptos do "sim" dão mais valor a ela e, por isso, têm uma posição eticamente superior à dos adversários.

Pautada por uma concepção coletiva de direito, a frente do "sim" responde que a proibição do comércio de armas de fogo não representa a perda de direitos individuais, mas a conquista de um direito comum à vida e à segurança. Isso porque, havendo menos armas em circulação, diminuiriam tanto os crimes de proximidade quanto a possibilidade de que bandidos viessem a roubar armas dos "cidadãos de bem"19. Além disso, argumenta-se, em uma clara incorporação da fala do adversário, que o voto no "sim" não representa uma interferência na vida dos outros, como sugerido pelo "não", mas um ato político de defesa da sociedade. Por meio de uma estratégia retórica, um dos apresentadores do programa do "sim" concorda, inicialmente, com a ideia de que um cidadão não deve interferir na vida do outro para, em seguida, estabelecer um vínculo em sentido contrário àquele estabelecido pelo "não": "Nunca gostei de armas. Mas também nunca gostei de me meter na vida dos outros. Se alguém quisesse correr o risco, o problema não era meu. Mas é. Posso ser vítima de um bêbado desequilibrado, maluco ciumento, alucinado do trânsito... Se todos os seus vizinhos tivessem armas, você se sentiria mais seguro?" (PN, FS, 3/10).

É interessante notar a estratégia argumentativa empregada: usa-se o mesmo argumento de enquadramento mobilizado pela frente do "não" ("não devemos nos meter na vida dos outros") para submetê-lo a um processo de reenquadramento (Breton, 2003). Assim, confronta-se diretamente o enquadramento da "defesa do direito de escolha" argumentando-se que: a) ninguém tem o direito de matar (a partir do programa vespertino do dia 16/10, a frase "arma mata, e isso não é direito" é repetida quase diariamente até o fim da campanha); b) quando se trata de questões de interesse público, a vontade individual deve se subordinar ao bem-estar coletivo. A atriz Arlete Sales abre um dos programas do "sim" com a seguinte fala: "Que direito um homem tem de atirar na mulher em uma briga? Que direito alguém tem de ter uma arma em casa e atirar em uma criança? Muitas famílias sofrem porque alguém achou que tinha o direito de matar. O desejo de possuir uma arma, que é de poucos, não pode ser maior do que o direito à vida, que é de todos nós" (PN, FS, 8/10).

Em uma referência direta à campanha adversária, um dos apresentadores do programa do "sim" afirma: 
O programa do "não" diz que defende o direito das pessoas, mas não explica bem que direito é esse. Será que é direito um sujeito dormir com uma arma na cabeceira? Que direito é esse de alguém puxar uma arma numa discussão no trânsito? Que direito é esse que permite que um estudante vá pra escola armado e ponha em risco a vida de outros jovens? (PN, FS, 10/10).

Essas falas são interessantes porque representam não apenas a revisão de argumentos preexistentes no discurso do "sim" diante da argumentação do "não", mas a construção de um argumento dedicado essencialmente a problematizar o direito à legítima defesa e à liberdade individual em um assunto delicado como a posse de armas. Tal argumento não existiria na campanha do "sim" independentemente do discurso do "não". Ele demonstra a disposição para se ocupar com a problematização do argumento adversário.

O "sim" utiliza depoimentos de especialistas e entrevistas para enfatizar sua defesa de uma concepção coletiva de direito. Um médico diz que direito à vida é sinônimo de direito à saúde, e as pessoas não têm o direito de andar de bicicleta sem capacete ou de carro sem cinto de segurança. Uma estudante diz que "sua liberdade individual cede lugar aos direitos coletivos, às vontades coletivas" (PN, FS, 11/10). Nesse ponto, a frente do "sim" alega que o direito individual do cidadão - no caso, possuir uma arma - deve estar subordinado aos direitos coletivos, no caso, à redução da violência urbana e à melhoria da segurança pública. No mesmo programa, a frente afirma: "A proibição do comércio não tira nenhum direito das pessoas e ainda vai salvar muitas vidas. Ainda que fosse uma única vida, você não acha que valeria a pena?" (PN, FS, 11/10).

Fica evidente que o debate caminha para a própria definição da ideia de direitos, o que envolve uma discussão sobre o caráter da cidadania edificada por uma certa sociedade. Enquanto o "não" recorre à ideia de direitos individuais e naturais, a frente do "sim" se propõe a refletir sobre os direitos que os cidadãos devem ter e questiona a validade de uma cidadania sem balizas. O "sim" parte de uma concepção republicana, nos termos de Habermas (1995), para defender que cabe ao corpo de cidadãos instituir, coletivamente, os direitos em voga em uma dada sociedade e que tais valores não podem colocar o indivíduo acima da coletividade. 


\section{Direito à Vida em um Mundo sem Segurança?}

Para rebater os argumentos do "sim" a favor do "direito à vida", a frente do "não" encampa o discurso adversário, mas questiona qual é a melhor maneira de defender tal direito. O enquadramento geral ("a importância do direito à vida") não é negado. A frente do "não" não apenas concorda, mas afirma com veemência que o direito mais básico do cidadão é o direito à vida:

Você tem acompanhado nossa campanha, sabe que estamos aqui defendendo os direitos do cidadão. E, é claro, o direito básico é o direito à vida. Por isso, insistimos tanto pedindo que o governo faça o desarmamento dos bandidos, pois são eles, com suas armas ilegais, que tiram a vida do cidadão de bem. Pelo direito à vida, pelo direito do cidadão, vote "não" (PN, FN, 9/10).

A ideia propagada pelo "não" é que, em um país sem segurança, o melhor modo de garantir o direito à vida é possibilitar que cada um se defenda. O governo, ou melhor, a falta dele, acaba por se tornar o verdadeiro inimigo da vida, como deixa claro o seguinte depoimento de uma mãe: "O assassino que matou meu filho era produto do desgoverno. Que tipo de vida é essa que eles estão defendendo? Uma vida em que a população vive ameaçada atrás das grades?" (PN, FN, 3/10). A estratégia consiste em contestar a qualidade de vida do cidadão brasileiro afirmando que a vida da qual o programa do "sim" se diz defensora é indigna e que nela o cidadão está constantemente ameaçado pelos bandidos.

Na argumentação construída pela frente do "não", dentro do enquadramento mais amplo da perda de direitos, o governo aparece como incapaz de garantir os direitos individuais básicos dos cidadãos. Defende-se que direitos fundamentais, como educação, segurança, trabalho, moradia e alimentação, deveriam ser fornecidos pelo Estado, embora não o sejam. Além de ser falho nesse sentido, o Estado ainda quereria tirar do cidadão o direito de defender-se, de ter uma arma ou de poder escolher tê-la. Um professor de história e geografia diz:

Democracia não é só votar, é o direito de eu ter uma arma, comer, trabalhar, viver, ter segurança. O Estado me deve tantos direitos, ele está em falta comigo. E direitos primordiais na vida de todos, educação, segurança... Como, num momento desses, o Estado vem me forçar e me tirar 
o direito de ter uma arma? Mesmo que eu não compre a arma, tenho que ter o direito (PN, FN, $7 / 10)$.

$\mathrm{O}$ argumento afirma que, além de incompetente na garantia da segurança pública e no combate ao contrabando e à criminalidade, o Estado ainda quer "prejudicar o cidadão de bem", que não é o culpado pela violência: "Antes de terminar este programa, eu queria deixar uma mensagem de esperança para o cidadão brasileiro que, muitas vezes, até depende do governo para conseguir direitos básicos, como saúde, educação, moradia e segurança. Esses direitos o governo não lhe dá, por isso você não pode abrir mão de um direito que é seu" (PN, FN, 14/10).

Desse modo, inverte-se a defesa do "direito à vida" por meio da ligação da discussão à questão da segurança pública. A vida do cidadão seria ameaçada pelos bandidos, sendo preciso opor-se ao poderio armamentista destes ${ }^{20}$.

A frente do "sim" não poderia discordar das falhas e omissões do governo, mesmo porque o contexto em que se desenvolve o debate do referendo é marcado pelo sentimento de desamparo ocasionado pelas então recém-descobertas evidências da existência de corrupção no governo federal. É nesse sentido que a resposta formulada pela frente do "sim" se pauta pela máxima: "Precisamos fazer a nossa parte e exigir que o governo faça a dele". Demonstra-se, pois, concordar com a afirmação de que o governo não combate a criminalidade com eficácia, mesmo porque seria muito difícil discordar dela. Admite-se que a violência tem muitas causas a serem combatidas, mas afirma-se que a proibição é um importante passo para a mudança:

O Brasil é marcado pela desigualdade social e a violência urbana. Mudam governos e não investem em segurança, [temos] desemprego e exclusão social, policiais mal remunerados e trabalhando em péssimas condições. Os problemas são muitos e, para piorar, 15 milhões de armas nas mãos de civis. $\mathrm{O}$ resultado disso tudo: o triste título de campeão mundial em mortes por armas de fogo (PN, FS, 9/10).

As condições sociais não são colocadas, nesse ponto, como motivo para armar-se, mas, pelo contrário, como imperativo para o desarmamento. É curioso perceber como os adversários do debate abordam, estrategicamente, uma mesma situação-problema (a violência no país) conscientes de que o lado oposto tem argumentos defensáveis para ex- 
plorar tal situação a seu favor e de que é preciso, portanto, abordar a situação para desconstruir a argumentação adversária. O referendo seria, então, uma oportunidade única para que os cidadãos agissem a fim de reduzir a violência. Seria o momento de as pessoas comuns assumirem responsabilidades pelas mudanças sociais que tanto demandam. Faz-se preciso, pois, valorizar esse momento decisório, assim como o estatuto que o gerou.

\section{Importância do Referendo para a Cidadania}

Partindo da ideia de que os cidadãos precisam "fazer a sua parte" e que "isso é ser cidadão", a frente do "sim" argumenta que o voto no referendo também é um direito de escolha do cidadão, o direito de decidir pela proibição ou não. Nota-se, aqui, que o "sim" encampa a ideia de que as pessoas têm direito de escolher para falar do próprio caráter de construção social dos direitos. Busca-se, portanto, valorizar o referendo e aquilo que ele representa, interpretando-o como uma possibilidade de transformação social. Em vários programas, o locutor diz que "o referendo é uma conquista da sociedade, é um direito seu, diga 'sim' à vida" (PN, 4/10; PN, 5/10; PN, 8/10; PN, 10/10).

Ressalta-se o fato de que a própria aprovação do Estatuto do Desarmamento resultou de um desejo do povo e foi uma conquista da sociedade. A consulta popular, por meio do referendo, seria um processo altamente democrático. A locutora diz: "Uma conquista de milhares de famílias que perderam pessoas queridas vítimas de armas de fogo. $\mathrm{O}$ Congresso Nacional, atendendo ao apelo e à mobilização popular, aprovou o Estatuto do Desarmamento, uma lei que amplia o direito à vida" (PN, FS, 7/10). Em uma referência direta à campanha adversária, o jornalista Fausto Barbosa diz:

Muito se fala em direito. Pense comigo, você conhece alguma forma mais democrática de resolver uma questão do que ouvir uma população inteira? Existe respeito maior ao direito do povo do que permitir que todos decidam? Existe atitude mais democrática do que aceitar a vontade da maioria? O referendo é um direito seu. No dia 23, diga "sim". Você tem o direito de defender sua vida (PN, FS, 8/10).

O enquadramento delineado pelo "sim" (referendo = direito) é, curiosamente, reincorporado pelo próprio "não" e acaba se tornando comum aos dois lados ao longo da campanha. Isso se deve à sua eficiência, afinal, é bastante cabível vincular o referendo a um processo demo- 
crático em que o cidadão exerce seu direito de escolha. Na verdade, não defender a importância do voto seria quase um suicídio político. $\mathrm{O}$ "não", porém, utiliza o enquadramento estabelecido para reforçar a ideia de que o voto no "sim" consistiria em um desperdício desse direito de escolha oferecido ao cidadão. Um empresário dá seu depoimento: "Acho que você tem, no voto, a forma de exercer um direito. Nesse caso do referendo das armas, se você abrir mão disso, será muito difícil conseguir reverter essa situação. Desarmar o cidadão de bem não é forma de combater a violência" (PN, FN, 7/10).

Se é comum a ideia de que o voto no referendo é um direito do cidadão, o "não" a coloca nos seguintes termos: votar "sim" seria abrir mão do poder ou da força daquele voto e, portanto, abrir mão daquele direito. Uma vez mais, assinala-se que a estratégia adotada pelo "não" é pautada pela ideia do medo de perder direitos.

\section{Cidadania de Desiguais?}

Da ideia de que a proibição da comercialização de armas significa "abrir mão de direitos", a frente do "não" retira mais uma conclusão: uma vitória do "sim" geraria uma cidadania estratificada, o que, por definição, seria inconcebível:

A Constituição brasileira diz que todos são iguais perante a lei, mas, se a proibição que o governo quer for aprovada, o Brasil vai ter três classes de pessoas diferentes, uns com mais direitos que os outros. Quer ver só? Se a proibição for aprovada, os privilegiados, aqueles que têm muito dinheiro, sempre vão poder contratar seguranças armados pra se proteger, apesar de a venda de armas estar proibida. Quem já tem arma hoje, continua com ela, mas a venda de munição estará proibida. Quem nunca teve uma arma, nunca mais terá o direito de ter. Eu disse nunca mais $(\mathrm{PN}, \mathrm{FN}, 6 / 10)$.

$\mathrm{O}$ argumento apresentado estabelece um entrecruzamento entre o eixo dos direitos e o eixo econômico, já que o motivo pelo qual a proibição geraria classes de pessoas diferentes diz respeito ao poder aquisitivo delas. O locutor do programa do "não" diz que o mercado de equipamentos de segurança cresceu muito nos últimos anos: "Nos bairros de classe média, as cercas elétricas e as câmeras de vídeo são retrato da insegurança, já que a segurança pública não funciona, o cidadão se protege como pode. [...] Nos bairros nobres, de gente rica, os gastos com segurança atingem valores surpreendentes" (PN, FN, 12/10). A apresenta- 
dora Carmen Cestari diz que a campanha do "não" não tem "artistas famosos que vivem em condomínios cercados de toda a segurança". Os artistas de tal campanha seriam "o povo brasileiro, o agricultor, o policial aposentado, gente como você, que precisa se proteger e não quer perder seus direitos" (PN, FN, 2/10).

Além disso, a campanha do "não" se apoia em argumentos de testemunho, que corroboram o enquadramento estabelecido. Apela-se para o vínculo analógico dos exemplos no intuito de dar consistência ao enquadramento sugerido. Um comerciante afirma que não tem segurança porque não tem como pagar por ela, e o governo não a garante ao cidadão. O discurso autorizado do presidente da Abrevis (Associação Brasileira de Empresas de Vigilância e Segurança) também é utilizado. Ele conta que "segurança é coisa cara. Segurança de pessoa privada, física, custa pelo menos 100 mil reais por mês". O locutor afirma:

A angústia pela falta de segurança vai aumentar se essa proibição, que o governo quer, for aprovada. Na prática, a proibição que o governo quer vai criar três classes diferentes de pessoas: os privilegiados, que podem pagar por seguranças armados e carros blindados; os que já têm sua arma, mas não vão poder comprar munição; e os que nunca tiveram uma arma e nunca vão poder ter (PN, FN, 12/10).

A apresentadora conclui: "Os ricos vão poder continuar comprando a sua segurança. Os pobres vão ficar à mercê dos bandidos e da falta de segurança [...]. Se fosse feita a proibição, o princípio de que todos os cidadãos são iguais perante a lei seria quebrado".

Esse enquadramento que opõe ricos e pobres, de fácil ressonância na sociedade, é incorporado pela frente do "sim", que estabelece vínculos opostos àqueles argumentados pelo "não". Afirma-se que não é a proibição que gera classes de pessoas diferentes, mas sim o direito de comprar armas, que é um direito de poucos:

A propaganda do "não" fala em direito de comprar uma arma. Ora, comprar um revólver no Brasil, hoje, com toda a papelada, custa pelo menos três mil reais. Quem pode gastar um dinheiro desses com uma arma? Cento e setenta milhões dos brasileiros ganham menos de três mil reais por mês. O que a propaganda do "não" defende é o direito dos ricos de continuar comprando armas, armas que podem ser roubadas por bandidos e matar mais brasileiros (PN, FS, 17/10). 
Ter uma arma sem registro é crime, dá cadeia. Ter uma arma registrada, com toda a papelada, custa muito caro, mais de três mil reais. Só rico pode pagar. Na prática, o direito de comprar uma arma é só para o rico. O problema é que a arma comprada na loja, pelo rico, um dia acaba na mão do bandido, e vai assaltar, ferir e matar brasileiros (PV, FS, 19/10).

Como se nota, no jogo argumentativo entre as frentes, cada uma afirma que o voto a favor do adversário contribuiria para a geração de classes de pessoas diferentes, resultando sempre no prejuízo dos mais pobres e humildes. Partindo de uma mesma base, cada frente estabelece vínculos argumentativos diferentes, que respondem uns aos outros. Ambas concordam com a crítica à divisão da sociedade em classes de cidadãos, mas interpretam que isso seria fruto de causas distintas. Embora o "não" parta, aqui, da defesa de um direito coletivo à igualdade, defende que este só pode ser conquistado se cada pessoa tiver os mesmos direitos. Já o argumento do "sim" indica que os direitos não são apenas normas instituídas, mas algo que se exerce. Assim, somente os mais ricos poderiam exercer um suposto direito de adquirir uma arma, e isso reforçaria as desigualdades.

A frente do "não" tenta desqualificar o argumento propagado pelo "sim" afirmando que não é o direito de comprar armas que está em questão. Reitera-se a ideia de que a classe economicamente inferior é a que mais sofre com a violência e tenta-se deslocar a discussão de volta para a questão da perda de um direito, dizendo-se, agora, que tal perda é ainda mais grave quando se trata de pessoas pobres, que têm poucos direitos garantidos:

Realmente os mais pobres acabam sendo os mais castigados. Mais do que poder comprar armas, os ricos podem se isolar com seguranças particulares em casas que são verdadeiras fortalezas. Podem até se mudar para o exterior. Os pobres ficam do lado de fora e são eles que mais sofrem com a violência, convivendo no dia a dia com o banditismo. $O$ que está em discussão não é quem pode ou não comprar uma arma, até porque há quem não possa comprar hoje, mas talvez possa comprar um dia, se quiser. A discussão real, verdadeira, é outra. É sobre perder ou manter seus direitos. É sobre tirar um direito de quem precisa, e ninguém mais do que os mais pobres precisam ter seus direitos respeitados (PN, FN, 19/10; ênfase do autor).

A estratégia, aí, é buscar o reenquadramento da questão. Desloca-se a tela interpretativa sugerida pelo "sim" questionando-a diretamente ("o que está em discussão não é quem pode ou não comprar uma 
arma"). Propõe-se, então, enquadrá-la pelo enfoque da necessidade de proteger os direitos (presentes e futuros) dos pobres, tão desrespeitados. Essa proteção não fala do exercício efetivo dos direitos, mas de sua garantia como princípio; princípio esse que pode vir a ser útil no futuro ("há quem não possa comprar hoje, mas talvez possa comprar um dia").

Nessa defesa por princípios naturais, individuais e universais, ganha nova ênfase o tema da liberdade: “Olá. Hoje vamos falar em liberdade. A liberdade é da natureza do ser humano, está dentro de cada um de nós, o direito do cidadão é uma conquista. Por isso, é importante o que está acontecendo em nosso país nesses dias, quando brasileiros de todos os rincões resolveram lutar por seus direitos" (PN, FN, 16/10).

O dilema entre direitos individuais e coletivos é resolvido por meio da estratégia liberal segundo a qual, garantindo-se o indivíduo, a coletividade estará bem: "A ameaça à liberdade individual põe em risco a democracia de todos. Defenda sua liberdade" (PN, FN, 16/10). E os cidadãos são convocados para defender esses princípios: “Decidir sobre o rumo de sua vida é um direito sagrado de todos os cidadãos. Defenda sua liberdade" (PN, FN, 16/10). O programa termina com a seguinte fala da apresentadora, que é repetida no último dia de campanha:

Liberdade não é apenas uma palavra, mas sim um dos sentimentos fundamentais meu, seu, de todos os seres humanos. O nosso hino da independência canta a liberdade dessa brava gente brasileira. Você sabe do que eu estou falando, uma brava gente, a quem os governos pouco ajudam, mas uma brava gente que não perde a esperança na luta pela vida. Um povo que supera tudo e ainda tem tempo pra ser alegre e cantar a sua liberdade. Liberdade de ir e vir, liberdade de falar, liberdade de amar, liberdade de decidir sobre a própria vida. Ser brasileiro é assim, mas ser brasileiro também é ser consciente, responsável para preservar a nossa liberdade. É hora de dizer "não". Não vão mexer nos meus direitos! Não! Não vamos deixar que tirem um pedaço da nossa liberdade! (PN, FN, 16/10; PN, FN, 20/10) ${ }^{21}$.

Como se nota, o termo "não" é usado para se contrapor ao que se afirma serem ameaças à liberdade. $\mathrm{O}$ tom emotivo e os vários elogios ao povo brasileiro ("essa brava gente") buscam conquistar os membros da audiência, criando as condições para que o argumento seja aceito. A resposta ao "sim" sugere que as liberdades individuais não precisam 
A Cooperação na Deliberação Pública: Um Estudo de Caso sobre o Referendo...

ser submetidas ao bem comum, porque o que quer que as ponha em risco é um ataque à democracia.

\section{CONSIDERAÇÕES FINAIS}

A breve análise apresentada na seção anterior sugere a existência de um debate complexo e multifacetado acerca do referendo. Nesse processo, os atores envolvidos na discussão não podem simplesmente reiterar suas perspectivas, sob pena de se tornarem publicamente fracos. Mesmo que, muitas vezes, os enquadramentos gerais se mantenham bastante firmes, a reciprocidade argumentativa emerge dos sucessivos ajustes de vínculos argumentativos promovidos por cada frente. Para que se defenda o argumento mais amplo, é preciso exemplificá-lo, recorrer a especialistas, explicar suas causas e consequências. Nesses desdobramentos, uma frente se coloca em oposição à outra, e cada uma delas precisa dialogar com detalhes da construção argumentativa adversária.

Isso fica bastante claro quando se observam os rumos tomados pelo debate do referendo no que diz respeito à questão dos direitos. O discurso que configura cada campanha se constitui no espaço interacional entre ambas, que é também atravessado pelos potenciais telespectadores. Isso significa que cada frente não dialoga apenas com a adversária, mas com os discursos socialmente disponíveis, em uma espécie de constelação discursiva, para usar os termos de Dryzek (2000). Um estudo dessa constelação requereria uma análise diacrônica e transversal para captar os argumentos que se tornam socialmente circulantes em várias esferas discursivas (Hendriks, 2006).

Embora o intuito não tenha sido realizar tal análise, a observação do debate entre as duas frentes nas campanhas do HGPE explicita a construção dialógica e recíproca dos lances argumentativos que compõem o debate do referendo. Essa dialogicidade é a base da cooperação e da reciprocidade deliberativas. Seria interessante, ainda, refletir sobre os diferentes níveis de reciprocidade e o impacto desses níveis na consolidação de processos deliberativos. Tais níveis variam de acordo com o tipo de resposta concedida aos outros interlocutores e com a forma como o discurso do outro é encampado no próprio argumento. Partir dessa ideia básica de co-operação e refiná-la em estudos que apontem qualidades e déficits de diferentes níveis de reciprocidade parece um frutífero veio de pesquisa. 
O presente artigo, todavia, ateve-se a demonstrar que, sob um enfoque deliberacionista, reciprocidade e cooperação não precisam ser entendidas a partir da ideia de altruísmo. Buscou-se evidenciar tal ponto por meio do debate do referendo das armas, no qual cada frente constrói e publiciza suas perspectivas a partir dos filtros que surgem nos discursos oponentes. Não basta, portanto, defender o "direito à vida" ou o "direito à liberdade de escolha". É preciso explicar em que consistem esses direitos e rebater os argumentos a favor das posições adversárias. Nesse jogo, a cooperação não consiste, pois, na prática altruísta de ceder ao outro ou concordar com ele. Agonística, ela se mostra como uma co-operação (uma operação em conjunto) que é marcada pela reciprocidade na medida em que implica uma mutualidade. É em ouvir o outro, em encampar suas posições e em responder a elas que se constrói uma troca deliberativa. Esperar que a deliberação dependa de uma reciprocidade altruísta à moda de uma república de anjos é preestabelecer as condições que impossibilitam sua existência.

(Recebido para publicação em março de 2008)

(Versão definitiva em maio de 2009)

\section{NOTAS}

1. Os autores citam ainda três princípios substantivos que devem ser satisfeitos: liberdade básica, oportunidade básica e justiça de oportunidade.

2. Desenvolvido nos anos 1950 por Merrill Flood e Melvin Dresher, o dilema do prisioneiro reflete um tipo de situação interativa em que, embora não se trate de um jogo de soma zero, cada um dos envolvidos terá uma recompensa maior caso não coopere com o outro participante. No entanto, se ambos evitarem a cooperação, terão um resultado pior do que teriam se houvessem cooperado (Hofstadter, 1983). Ambos são tidos como racionais e egoístas, sendo que os dois sabem que provavelmente agirão da mesma maneira. Esse dilema tem mais uma armadilha: trata-se de um jogo de uma rodada só, não havendo possibilidade de retaliação. Estudos em torno desse dilema filosófico buscam transportar essa situação hipotética para experiências concretas e cotidianas, indagando-se sobre a racionalidade da cooperação. A ideia de cooperação aqui professada é a de que ela valerá a pena para cada indivíduo, porque é o melhor para todos. É isso o que aparece, por exemplo, em enfrentamentos teóricos da questão do free rider. Também é essa noção de cooperação implícita nos estudos que tentam desdobrar o dilema do prisioneiro em jogos mais complexos, com múltiplas jogadas. As interações sucessivas e a possibilidade de retaliação podem aumentar as chances 
da cooperação entre os participantes, porque os benefícios da reciprocidade - entendida como essa ação que, ao beneficiar o outro, também me beneficia - podem ser ensinados e aprendidos. É o que busca demonstrar Axelrod (1984) com seu famoso torneio de computadores, em que máquinas programadas para agir de maneiras determinadas se encontraram em uma sucessão de rodadas. Os resultados do torneio mostram que a demonstração de boa vontade em relação ao outro (desejo de cooperar) pode ser muito benéfica para o próprio ator. É importante salientar que Axelrod denomina o ato de cooperar por meio do termo nice, em inglês, implicando a gentileza que tem em mente ao pensar em tal conceito. Cooperar é ser gentil com o outro, visando a maximizar os próprios benefícios.

3. Baseada no estudo de Almond e Verba (1963) sobre as opiniões e comportamentos de cidadãos de cinco países democráticos, essa corrente busca entender a forma como a cultura (expressa em sentimentos, crenças e atitudes) tem um impacto fundamental sobre a estabilidade e a eficácia de regimes democráticos. É por isso que a literatura sobre cultura cívica devota grande atenção aos processos de socialização e às possibilidades de aperfeiçoar o exercício democrático a partir de transformações culturais (Almond, 1989; Putnam, 1996; Power e González, 2003; Inglehart, 2002; Pateman, 1992; Lijphart, 1989). Um elemento importante da chamada cultura cívica é a cooperação. Putnam (1996) deixa isso muito claro em seu estudo sobre a reforma institucional italiana processada a partir dos anos 1970. O autor defende que as interações face a face cooperativas, como aquelas engendradas por associações civis, são fundamentais para o estreitamento dos laços sociais, porque geram confiança e, assim, o que ele chama de capital social. Este remete à existência de redes sociais em que pessoas fazem coisas umas pelas outras. Em sua crítica a Putnam, Gomes (2008) lembra que a noção de capital social do autor se refere "a alguns aspectos da organização social que facilitam a coordenação e a cooperação dos indivíduos, proporcionando-lhes, em razão disso, benefícios mútuos" (ibidem:223). A reciprocidade geraria uma confiança generalizada nos outros sujeitos, vistos como cooperantes. Trabalhando juntos, os indivíduos seriam mais fortes e mais capazes, produzindo uma sociedade melhor.

4. Nota-se, nesse ponto, uma aparente inversão do chamado egoísmo moral de Bentham, mas que, no fundo, expressa a mesma perspectiva. O pensamento do filósofo utilitarista está assentado sobre dois pressupostos: as pessoas buscam seu próprio benefício, e ações morais promovem a felicidade da comunidade. Segundo Dinwiddy, Bentham acreditava que "ensinar os indivíduos a maximizar sua própria felicidade a longo prazo em áreas de conduta individuais [...] ajudaria a aumentar a felicidade agregada" (1989:31-32; tradução do autor). O bem-estar da sociedade é uma condição importante para que os indivíduos se deem bem.

5. Embora tal definição possa parecer bastante condescendente, são muito comuns os "debates" em que essa consideração dos interlocutores não ocorre de fato, já que os atores estão mais preocupados em repetir suas posições originais do que em ingressar em um diálogo. Se eles meramente repetem seus argumentos, sem ouvir e encampar as posições de outros interlocutores, não se pode falar em reciprocidade deliberativa.

6. Mota (2006) e Araújo e Santana (2006) traçam interessantes trajetórias do Estatuto do Desarmamento, explicando que, desde 1994, a ONG carioca Viva Rio chamou a atenção para o problema das armas, sendo que as ações se intensificaram no fim dos anos 1990. Merece destaque também a atuação do Instituto Sou da Paz em São Paulo. Em 
20 de fevereiro de 1997, foi aprovada a Lei no 9.437, que regulamentou o uso de armas e instituiu o Sinarm (Sistema Nacional de Armas) (Muylaert, 2006). Em 1999, organizou-se, com o apoio do então subsecretário de segurança pública do Rio de Janeiro, Luiz Eduardo Soares, um movimento pelo desarmamento e pela paz, que conseguiu aprovar uma lei estadual para proibir a comercialização de armas. Esta foi, todavia, derrubada por uma ação judicial iniciada pelo lobby das armas, mas a ideia gerou uma coleta nacional de assinaturas solicitando a proibição de armas de fogo no país. O então presidente Fernando Henrique Cardoso recebeu a lista com um milhão e duzentos mil nomes, mas o projeto ficou paralisado. No ano de 2002, foi organizada a Semana de Segurança Pública, cujos seminários apontaram para a necessidade de desarmar a população (Correa e Nunes, 2006). As lideranças do movimento passaram a adotar a estratégia da pressão social, por meio de atos públicos, passeatas, manifestações, campanhas e divulgação de pesquisas, que manteriam o tema na pauta das discussões públicas. Iniciou-se também uma luta no âmbito da política institucional pela apresentação e aprovação de um projeto de lei. Entre 2003 e 2005, "tramitaram na Câmara dos Deputados 14 proposições importantes que se relacionavam diretamente ao tema do referendo do desarmamento" (ibidem:127). Foram figuras importantes, nesse processo, Renan Calheiros, José Roberto Arruda, José Sarney, Antonio Carlos Magalhães Neto, Luiz Eduardo Greenhalgh e José Dirceu, além de articuladores da sociedade civil, como Antônio Rangel, Ignácio Cano e Rubem César Fernandes, e vários artistas. Com o forte apoio, a tramitação do projeto foi acelerada, tendo este sido sancionado em 23 de dezembro de 2003. Em 2004, iniciaram-se as campanhas de entrega voluntária de armas, que recolheram e destruíram mais de 450 mil delas (bem mais do que as 80 mil esperadas). Em 2005, travou-se nova luta política no Legislativo para a realização do referendo pela proibição da venda de armamentos prevista no art. 35 .

7. Vale registrar que, "apesar de todas essas 'lacunas' informacionais, os jornais contribuíram de forma significativa para proporcionar condições favoráveis à participação política informada por parte do cidadão. [...] A proibição sobre o comércio das armas apareceu, na cobertura dos jornais, como um tema de debate e não apenas como objeto de um tratamento de natureza 'episódica'" (Fuks e Novais, 2006:195).

8. Sobre o debate nos meios de comunicação convencionais, ver Maia, Buarque e Brischiliari (2006) e Fuks e Novais (2006).

9. Para uma análise da importância dos SPAMs e do "marketing viral na internet" para a vitória do "não", cf. Sorj (2006). De acordo com o autor, circularam pela rede diversos SPAMs, em tom pessoal, que propuseram teses conspiratórias, desqualificaram os argumentos do "sim" e relacionaram seus propositores a antigos ditadores, comunistas e fascistas. Outro aspecto curioso assinalado pelo autor é o constante ataque de hackers ao site do "sim", que, mesmo depois de transferido para um servidor nos Estados Unidos, chegou a receber nove mil ataques por hora.

10. Anastasia, Inácio e Novais (2006:19) apresentam interessante sistematização dos atores envolvidos no processo do referendo, bem como dos recursos de que cada um dispunha. Elas citam: 1) Poder Executivo (recursos: poderes de agenda e veto); 2) deputados e senadores (recursos: representação e delegação de responsabilidades); 3) ONGs, igrejas e movimentos sociais (com poder de persuasão, campanhas, mobilização, accountability); 4) lobby da bala (recursos: financeiros, pressão, influência, accountability); 5) mídia (recursos: informação, opinião); 6) frente do "sim" (recur- 
sos: institucionais, mobilização, persuasão, campanhas); 7) frente do "não" (recursos: institucionais, mobilização, persuasão, campanhas); 8) cidadãos (recursos: voto, accountability). Cabe registrar aqui que, neste artigo, se discorda da visão de que é possível pensar a mídia como um ator monolítico e como se ela apoiasse a proibição da comercialização das armas de fogo. Para uma visão mais nuançada do papel dos media no referendo, ver Maia, Buarque e Brischiliari (2006).

11. Sobre o modo como o "não" transformou uma situação desfavorável em favorável, ver Anastasia, Inácio e Novais (2006).

12. Sobre as especificidades das campanhas do referendo e do modo como enfocaram temáticas, e não personagens, ver também Fuks e Paiva (2006).

13. A respeito da crescente utilização do conceito de frame, ver Weaver (2007), Reese (2007) e Van Gorp (2007).

14. Fuks e Paiva (2006) realizaram uma organização dos discursos de cada frente por meio da ideia de núcleos argumentativos. Encontraram quatro núcleos do "não" (direitos do cidadão, causas da violência, consequências da violência e responsabilidade do Estado, além das críticas ao "sim") e três núcleos do "sim" (arma como causa, responsabilização, princípios e valores). Acredita-se, no entanto, que o foco em eixos argumentativos que atravessem as duas frentes se mostra mais interessante, por possibilitar a percepção do debate em um terreno temático comum, no qual cada frente constrói suas perspectivas. Cabe assinalar, ainda, que os núcleos apresentados por Fuks e Paiva (ibidem) não parecem dar conta de toda a dinâmica da campanha, deixando escapar os argumentos econômicos, por exemplo. Isso fica claro quando se nota que $30 \%$ dos argumentos do "sim" não cabem em nenhum dos núcleos citados.

15. No primeiro caso, "deduziremos que a opinião defendida faz parte da realidade enquadrada" (Breton, 2003:113), em uma cadeia lógica de continuidade. No segundo, busca-se "estabelecer uma correspondência entre duas zonas do real até então separadas" (ibidem:114). Um exemplo de vínculo dedutivo ocorre quando se apresenta a opinião sustentada como "uma causa ou um efeito de alguma coisa sobre a qual existe um acordo" (ibidem:127). Casos de vínculos analógicos são as comparações, as metáforas e os exemplos (ibidem:130-142).

16. Serão adotadas, a partir de agora, as seguintes siglas para citações: PV (programa vespertino), PN (programa noturno); FN (frente do "não"), FS (frente do "sim"); data (dia/mês).

17. Vale ressaltar que o próprio cenário do programa, sua abertura e seu encerramento apelam para as noções de patriotismo, democracia, liberdade e cidadania, por meio de imagens da bandeira do Brasil e de multidões nas ruas cantando o hino nacional.

18. Cabe ressaltar que, enquanto a primeira estratégia é a base da argumentação do "sim" desde o primeiro programa da frente, a outra representa um argumento construído ao longo da campanha, em um claro ajuste de discurso visando responder a argumentação básica do "não", isto é, a defesa do direito de legítima defesa.

19. Tais questões são mais bem analisadas no âmbito do eixo da segurança pública. Para torná-las mais claras aqui, porém, são citados alguns exemplos. No primeiro programa do "sim", a apresentadora Angélica e a atriz Maitê Proença respondem a várias perguntas feitas por pessoas comuns. Uma das perguntas é a seguinte: “Não é melhor desarmar o bandido do que desarmar o cidadão?", ao que a atriz responde: "A proibição ajuda a desarmar o bandido, porque boa parte das armas que a polícia pega 
nas mãos dos bandidos foi roubada de um cidadão de bem. Bandido não compra arma em loja" (PV, FS, 1이시). O argumento é reiterado ao longo de toda a campanha. Quanto aos crimes de proximidade, a ideia é que a maioria das mortes por armas de fogo resulta de motivos fúteis, como raiva, revolta, tensão, álcool e ciúme, ou de acidentes domésticos, não se tratando de crimes planejados por bandidos. Cita-se uma pesquisa da Secretaria de Segurança Pública de São Paulo, que diz que 95\% das mortes causadas por armas de fogo ocorrem por motivos fúteis, e não por assaltos (PN, FS, 5/10).

20. Observa-se, em uma análise do eixo da segurança pública, que o "sim", ao falar dos crimes de proximidade, mobiliza um enquadramento que foge de posições maniqueístas. Afirma-se que não faz muito sentido distinguir entre cidadãos de bem e bandidos quando o assunto é morte por armas de fogo, ao passo que a frente do "não" formula seus contra-argumentos a partir de um enquadramento mais usual, que apresenta uma dicotomia entre o bem e o mal.

21. Ao longo dos vinte dias de campanha, alguns programas foram veiculados mais de uma vez. Portanto, quando se cita a data em que determinada fala foi veiculada, trata-se da primeira vez em que isso ocorreu. Pode ser que a mesma fala tenha sido exibida também em outro dia e horário. Isso se aplica aos programas de ambas as frentes.

\section{REFERÊNCIAS BIBLIOGRÁFICAS}

ADLOFF, Frank e MAU, Steffen. (2006), “Giving Social Ties, Reciprocity in Modern Society". Archives of European Sociology, vol. 47, no 1, pp. 93-123.

ALMOND, Gabriel. (1989), “The Intellectual History of the Civic Culture Concept", in G. Almond e S. Verba (eds.), The Civic Culture Revisited. Newbury Park, Sage Publications, pp. 1-36.

e VERBA, Sidney. (1963), The Civic Culture: Political Attitudes and Democracy in Five Nations. Princeton, Princeton University Press.

ANASTASIA, Fátima, INÁCIO, Magna e NOVAIS, Raquel. (2006), “Referendo e Democracia: Perdas e Ganhos", in M. Inácio, R. Novais e F. Anastasia (orgs.), Democracia e Referendo no Brasil. Belo Horizonte, Editora UFMG, pp. 15-33.

ARAÚJO, Paulo M. e SANTANA, Luciana. (2006), “O Referendo sobre o Comércio de Armas: Processo Decisório, Representação Política e Participação Popular na Democracia Brasileira", in M. Inácio, R. Novais e F. Anastasia (orgs.), Democracia e Referendo no Brasil. Belo Horizonte, Editora UFMG, pp. 75-120.

AXELROD, Robert. (1984), The Evolution of Cooperation. New York, Basic Books.

BENNETT, W. Lance et alii. (2004), “Managing the Public Sphere: Journalistic Construction of the Great Globalization Debate". Journal of Communication, vol. 54, no 3, pp. 437-455. 
A Cooperação na Deliberação Pública: Um Estudo de Caso sobre o Referendo...

BOHMAN, James. (1996), Public Deliberation: Pluralism, Complexity, and Democracy. Cambridge, MIT.

BRADY, John S. (2004), "No Contest? Assessing the Agonistic Critiques of Jürgen Habermas's Theory of the Public Sphere". Philosophy \& Social Criticism, vol. 30, no 3, pp. 331-354.

BRETON, Philippe. (2003), A Argumentação na Comunicação. Bauru, EDUSC.

CALLAGHAM, Karen e SCHNELL, Frauke. (2001), “Assessing the Democratic Debate: How the News Media Frame Elite Policy Discourse". Political Communication, vol. 18, no 2, pp. 183-213.

CHAMBERS, Simone e KOPSTEIN, Jeffrey. (2001), "Bad Civil Society". Political Theory, vol. 29 , no 6, pp. 837-865.

CHONG, Dennis e DRUCKMAN, James N. (2007a), "Framing Theory". Annual Review of Political Science, vol. 10, pp. 103-126.

. (2007b), "A Theory of Framing and Opinion Formation in Competitive Elites Environments". Journal of Communication, vol. 57, no 1, pp. 99-118.

COOKE, Maeve. (2000), "Five Arguments for Deliberative Democracy". Political Studies, vol. 48, no 5, pp. 947-969.

CORREA, Izabela e NUNES, Felipe. (2006), “Democracia, Poder Legislativo e Mecanismos Institucionais Participativos", in M. Inácio, R. Novais e F. Anastasia (orgs.), Democracia e Referendo no Brasil. Belo Horizonte, Editora UFMG, pp. 121-155.

CUNHA, Christina Vital da. (2006), “'Referendo das Armas': Propaganda Televisiva e Percepções da População". Comunicações do ISER, no 62 (Referendo do Sim ao Não: Uma Experiência da Democracia Brasileira), pp. 57-70.

DAHLBERG, Lincoln. (2005), “The Habermasian Public Sphere: Taking Difference Seriously?". Theory and Society, vol. 34, no 2, pp. 111-136.

DINWIDDY, John. (1989), Bentham. Oxford, Oxford University Press.

DRUCKMAN, James N. (2004), "Political Preference Formation: Competition, Deliberation and the (Ir)Relevance of Framing Effects". American Political Science Review, vol. 98, no 4, pp. 671-686.

e NELSON, Kjersten R. (2003), “Framing and Deliberation: How Citizens' Conversations Limit Elite Influence". American Journal of Political Science, vol. 47, no 4, pp. 729-745.

DRYZEK, John S. (2000), Deliberative Democracy and Beyond: Liberals, Critics, Contestations. New York, Oxford University Press.

e NIEMEYER, Simon. (2006), "Reconciling Pluralism and Consensus as Political Ideals". American Journal of Political Science, vol. 50, no 3, pp. 634-649.

ENTMAN, Robert M. (1993), "Framing: Toward a Clarification of a Fractured Paradigm". Journal of Communication, vol. 43, no 4, pp. 51-58.

FUKS, Mario e NOVAIS, Raquel. (2006), “O Referendo e a Cobertura da Imprensa: Uma Análise do Ambiente Informacional”, in M. Inácio, R. Novais e F. Anastasia (orgs.), Democracia e Referendo no Brasil. Belo Horizonte, Editora UFMG, pp. 180-205. 
FUKS, Mario e PAIVA, Daniela. (2006), “Persuasão e Deliberação sobre Políticas Públicas. A Propaganda Política no 'Referendo das Armas'”, in M. Inácio, R. Novais e F. Anastasia (orgs.), Democracia e Referendo no Brasil. Belo Horizonte, Editora UFMG, pp. 206-248.

GAMSON, William e MODIGLIANI, André. (1989), “Media Discourse and Public Opinion on Nuclear Power: A Constructionist Approach". American Journal of Sociology, vol. 95, no 1, pp. 1-37.

GOFFMAN, Erving. (1986), Frame Analysis: An Essay on the Organization of Experience. New York, The Mapple Press.

GOMES, Wilson. (2008), “Capital Social, Democracia e Televisão em Robert Putnam”, in W. Gomes e R. Maia, Comunicação e Democracia: Problemas e Perspectivas. São Paulo, Paulus, pp. 221-274.

GUTMANN, Amy e THOMPSON, Dennis. (1996), Democracy and Disagreement: Why Moral Conflict Cannot be Avoided in Politics, and What Should be Done About It. Cambridge, Harvard University Press.

HABERMAS, Jürgen. (1983), The Theory of Communicative Action: Reason and the Rationalization of Society. Boston, Beacon Press, vol. 1.

. (1995), “Três Modelos Normativos de Democracia". Lua Nova, no 36, pp. 39-53.

. (1997), Direito e Democracia: Entre a Facticidade e a Validade. Rio de Janeiro, Tempo Brasileiro.

. (2002), A Inclusão do Outro: Estudos de Teoria Política. São Paulo, Edições Loyola.

. (2006), "Political Communication in Media Society: Does Democracy Still Enjoy an Epistemic Dimension? The Impact of Normative Theory on Empirical Research". Communication Theory, vol. 16, pp. 411-426.

HENDRIKS, Carolyn M. (2006), “Integrated Deliberation: Reconciling Civil Society's Dual Role in Deliberative Democracy". Political Studies, vol. 54, pp. 486-508.

HOFSTADTER, Douglas R. (1983), “Metamagical Themas: Computer Tournaments of the Prisoners' Dilemma Suggest how Cooperation Evolves". Scientific American, vol. 248, no 5, pp. 14-21.

INGLEHART, Ronald. (2002), “Cultura e Democracia”, in L. E. Harrison e S. P. Huntington (orgs.), A Cultura Importa: Os Valores que Definem o Progresso Humano. Rio de Janeiro/São Paulo, Record/Duas Cidades, pp. 133-153.

JAMES, Michael R. (2004), Deliberative Democracy and the Plural Polity. Lawrence, University Press of Kansas.

LEVIN, David. (2005), “Framing Peace Policies: The Competition for Resonant Themes”. Political Communication, vol. 22, no 1, pp. 83-108.

LIJPHART, Arend. (1989), “The Structure of Inference”, in G. Almond e S. Verba (eds.), The Civic Culture Revisited. Newbury Park/London/New Delhi, Sage Publications, pp. 37-56.

LISSOVSKY, Maurício. (2006), "A Campanha na TV e a Desventura do Sim que era Não". Comunicações do ISER, no 62 (Referendo do Sim ao Não: Uma Experiência da Democracia Brasileira), pp. 32-49. 
MACEDO, Stephen. (1999), "Introduction", in S. Macedo (ed.), Deliberative Politics: Essays on Democracy and Disagreement. New York/Oxford, Oxford University Press, pp. 3-14.

MAIA, Rousiley (coord.). (2008), Mídia e Deliberação. Rio de Janeiro, Editora FGV.

MAIA, Rousiley, BUARQUE, Adriana e BRISCHILIARI, Rafael. (2006), A Dinâmica da Deliberação: Indicadores do Debate Midiado sobre o Referendo do Desarmamento. Trabalho apresentado no I Congresso Anual da Associação Brasileira de Pesquisadores de Comunicação e Política (Compolítica), Salvador, 28 de novembro-1o de dezembro.

MAUSS, Marcel. (1974), “Ensaio Sobre a Dádiva. Forma e Razão da Troca nas Sociedades Arcaicas", in M. Mauss, Sociologia e Antropologia. São Paulo, Editora Pedagógica e Universitária, vol. 2, pp. 39-184.

MEAD, George Herbert. (1993), Espíritu, Persona y Sociedad: Desde el Punto de Vista del Conductismo Social. México, Paidós.

MOTA, Maria Aparecida R. (2006), “O Referendo de Outubro/2005: Das Conquistas Plurais à Derrota Singular". Comunicações do ISER, no62 (Referendo do Sim ao Não: Uma Experiência da Democracia Brasileira), pp. 7-22.

MOUILLAUD, Maurice. (2002), O Jornal: Da Forma ao Sentido (2a ed.). Brasília, Ed. UnB.

MUYLAERT, Sérgio. (2006), "Comércio de Armas de Fogo: Seqüelas do Referendo". Comunicações do ISER, no 62 (Referendo do Sim ao Não: Uma Experiência da Democracia Brasileira), pp. 50-56.

PATEMAN, Carole. (1992), Participação e Teoria Democrática. Rio de Janeiro, Paz e Terra.

PORTO, Mauro. (2004), “Enquadramentos da Mídia e Política”, in A. Rubim (org.), Comunicação e Política: Conceitos e Abordagens. Salvador/São Paulo, EDUFBA/Unesp, pp. 74-104.

POWER, Timothy e GONZÁLEZ, Júlio. (2003), “Cultura Política, Capital Social e Percepções sobre a Corrupção: Uma Investigação Quantitativa em Nível Mundial”. Revista de Sociologia e Política, no 21, pp. 51-69.

PUTNAM, Robert D. (1996), Comunidade e Democracia: A Experiência da Itália Moderna. Rio de Janeiro, Editora FGV.

REESE, Stephen D. (2007), "The Framing Project: A Bridging Model for Media Research Revisited". Journal of Communication, vol. 57, no 1, pp. 148-154.

SORJ, Bernardo. (2006), "Internet, Espaço Público e Marketing Político: Entre a Promoção da Comunicação e o Solipsismo-Moralista". Comunicações do ISER, no 62 (Referendo do Sim ao Não: Uma Experiência da Democracia Brasileira), pp. 23-31.

STEINBERG, Marc W. (1998), "Tilting the Frame: Considerations on Collective Action Framing from a Discursive Turn". Theory and Society, vol. 27, no 6, pp. 845-872.

VAN GORP, Baldwin. (2007), "The Constructionist Approach to Framing: Bringing Culture Back In". Journal of Communication, vol. 57, no 1, pp. 60-78.

WARREN, Mark. (2006), "What Should and Should Not Be Said: Deliberating Sensitive Issues". Journal of Social Philosophy, vol. 37, no 2, pp. 163-181.

WEAVER, David. (2007), "Thoughts on Agenda Setting, Framing and Priming". Journal of Communication, vol. 57, no 1, pp. 142-147. 


\section{ABSTRACT \\ Cooperation in Public Deliberation: A Case Study on the Referendum to Ban the Sale of Firearms in Brazil}

This article discusses the concepts of cooperation and reciprocity, based on a deliberative view of democracy. The authors defend that such concepts do not depend on altruism, but on mutual consideration between interlocutors in a process of exchange of arguments. Based on this idea, the article analyzes the debates waged in Brazil over a referendum to ban the sale of firearms. The investigation looked at campaign advertising through the lenses of frame analysis. The study adopted frame analysis methodology. The results showed that the discourses representing each campaign were shaped within the interactional space between the two, thereby revealing a reciprocity or cooperation between the interlocutors.

Key words: deliberation; cooperation; reciprocity; firearms referendum

\section{RÉSUMÉ}

La Coopération dans la Délibération Publique: Une Étude de Cas sur le Référendum Concernant l'Interdiction de Commercialisation des Armes à Feu au Brésil

Dans cet article, on discute les concepts de coopération et réciprocité selon le critère de délibération en démocratie. On pose que ces concepts ne découlent pas de l'altruisme, mais de la considération mutuelle entre interlocuteurs dans un processus d'échange d'arguments. À partir de cette idée, on analyse les débats engagés à l'occasion du référendum sur l'interdiction de la commercialisation des armes à feu, pendant les émissions de la Propagande Électorale Gratuite. La recherche s'est déroulée à partir de la méthodologie d'analyse d'encadrement. L'examen du sujet étudié montre que le discours qui donne forme à chaque campagne se constitue dans l'espace interactionnel existant entre elles, permettant qu'on parle de réciprocité ou de coopération entre les interlocuteurs.

Mots-clé: délibération; coopération; réciprocité; référendum sur les armes 